\title{
First reversible protonation of the all-nitrogen 1-aryl pentazole ring
}

\author{
R. N. Butler, John C. Stephens and John M. Hanniffy \\ Department of Chemistry, National University of Ireland, Galway, Ireland
}

Received 19 November 2003; revised 8 December 2003; accepted 18 December 2003

\begin{abstract}
At $-40^{\circ} \mathrm{C}$ in chlorosulfonic acid 1-aryl pentazoles were protonated at N-3. The N-3 atom showed a ${ }^{15} \mathrm{~N}$ NMR shielding shift of -60 to $-62 \mathrm{ppm}$. The $-\mathrm{N}_{5}$ ring is the highest member of the azole series.

(c) 2004 Elsevier Ltd. All rights reserved.
\end{abstract}

The existence of an unstable all-nitrogen five-membered ring, $\mathrm{ArN}_{5}$, the aryl pentazole system was first proved by Huisgen and $\mathrm{Ugi}^{1}$ who isolated examples at low temperatures in 1956. At normal ambient temperatures the ring degrades rapidly with $\mathrm{N}_{2}$ evolution giving aryl azides $\mathrm{Ar}-\mathrm{N}_{3}$. Since the discovery of the $\mathrm{Ar}-\mathrm{N}_{5}$ ring there has been much theoretical interest in its properties. $^{2}$ Little is known about its chemical behaviour other than the $\mathrm{N}_{2}$ evolution. Attempted reductions and oxidations have all resulted in destruction of the $\mathrm{Ar}-\mathrm{N}_{5}$ ring. ${ }^{2-4}$ One chemical property that has attracted particular theoretical attention is its basicity and its protonation site. ${ }^{5-8}$ A very weakly basic $\mathrm{p} K_{\mathrm{a}}$ of ca. $-8.9\left(\mathrm{p} K_{\mathrm{a}}\right.$ of the conjugate acid) has been theoretically estimated ${ }^{7,8}$ for $\mathrm{Me}-\mathrm{N}_{5}$ and a protonation site at $\mathrm{N}-3$ has been predicted for the ring. ${ }^{5-8}$ We have now used ${ }^{15} \mathrm{~N}$ NMR spectroscopy at $-40^{\circ} \mathrm{C}$ to examine the protonation of the aryl pentazoles $\mathbf{1}$ and $\mathbf{4}$ (Scheme 1). ${ }^{\dagger}$

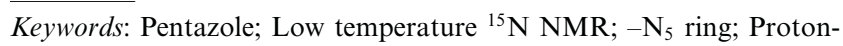
ation; Azole.

* Corresponding author. Tel.: +353-91-750315; fax: +353-91-525700; e-mail: r.debuitleir@nuigalway.ie

† Example of the procedure for preparation and purification of the aryl pentazoles: $p$-Anisidine $(0.28 \mathrm{~g}, 2.3 \mathrm{mmol})$ in $\mathrm{MeOH}\left(1.44 \mathrm{~cm}^{3}\right)$ was treated dropwise with concd $\mathrm{HCl}\left(0.36 \mathrm{~cm}^{3}\right)$ at $0-2{ }^{\circ} \mathrm{C}$. Slowly and with stirring, isoamyl nitrite $\left(0.34 \mathrm{~cm}^{3}, 2.5 \mathrm{mmol}\right)$ was added. The solution was allowed to stand for $20 \mathrm{~min}$ at $0-2{ }^{\circ} \mathrm{C}$ and then diluted with a $\mathrm{MeOH}-\mathrm{H}_{2} \mathrm{O}(1: 1 \mathrm{v} / \mathrm{v})$ mixture $\left(4.0 \mathrm{~cm}^{3}\right)$. A layer of petroleum spirit (bp $40-60^{\circ} \mathrm{C}, 22 \mathrm{~cm}^{3}$ ) was placed over the solution and the mixture cooled to $-35^{\circ} \mathrm{C}$. A precooled solution of terminal ${ }^{15} \mathrm{~N}$-labelled sodium azide $(0.15 \mathrm{~g}, 2.3 \mathrm{mmol})$ in a $\mathrm{MeOH}-\mathrm{H}_{2} \mathrm{O}$ $(60: 40 \mathrm{v} / \mathrm{v})$ mixture $\left(1.22 \mathrm{~cm}^{3}\right)$ was injected into the lower aqueous layer. A solid mixture of 1-(p-methoxyphenyl)pentazole and $p$-methoxyphenylazide separated and was filtered using a sintered glass funnel with a cooling jacket at $-40^{\circ} \mathrm{C}$. The solid was carefully and repeatedly washed with a $\mathrm{MeOH}-\mathrm{H}_{2} \mathrm{O}(60: 40 \mathrm{v} / \mathrm{v})$ mixture $\left(1.5 \mathrm{~cm}^{3}\right)$, precooled to $-55^{\circ} \mathrm{C}$, to give 1-( $p$-methoxyphenyl)pentazole. This procedure places ${ }^{15} \mathrm{~N}$-labels at the pentazole N-2 and N-3 sites. ${ }^{14}$
Protonation of a pyridine-type nitrogen atom in an azole ring causes a shielding shift of up to $-100 \mathrm{ppm}$, in the ${ }^{15} \mathrm{~N}$ signal. ${ }^{9,10}$ Using N-2 (N-5) and N-3 (N-4) ${ }^{15}$ N-labelled $p$-chlorophenyl pentazole $\mathbf{1}$ and $p$-methoxyphenyl pentazole 4 we have observed ring protonation at N-3. On removal of the proton the neutral pentazole was restored (Fig. 1 and Scheme 1). Figure 1A shows the ${ }^{15} \mathrm{~N}$ NMR spectrum of 1 at $-40^{\circ} \mathrm{C}$ in $\mathrm{CD}_{3} \mathrm{OD}-\mathrm{CD}_{2} \mathrm{Cl}_{2}(1: 1 \mathrm{v} / \mathrm{v})$. Figure $1 \mathrm{~B}$ shows the spectrum of 1 measured in $1: 1(\mathrm{v} / \mathrm{v})$ trifluoroacetic acid-trifluoroacetic anhydride at $-30^{\circ} \mathrm{C}$. In this trifluoroacetic acid medium only a low percentage of the pentazole molecules are protonated and the N-3 signal moves upfield by only $11.3 \mathrm{ppm}$, from 6.5 to $-4.8 \mathrm{ppm}$. This agrees with an exceptionally weak basicity for the ring. However at $-40^{\circ} \mathrm{C}$ in the superacid, chlorosulfonic acid $\left(\approx \mathrm{p} K_{\mathrm{a}}-12\right)^{11}$ (Fig. 1C, Scheme 1) the $\mathrm{N}-3$ signals of $\mathbf{1}$ and $\mathbf{4}$ are shifted upfield by 61.6 and $60.0 \mathrm{ppm}$ confirming full protonation of the pentazole. This is expected for a basic $\mathrm{p} K_{\mathrm{a}}$ of ca. -8.9 . The ${ }^{15} \mathrm{~N}$ shift of ca. $-61 \mathrm{ppm}$ is the average for the pentazole N-3 and $\mathrm{N}-4$, since N-3 and N-4 are equivalent, and is probably composed of ca. $-95 \mathrm{ppm}$ for the protonated N-3 (N-4) and ca. $-25 \mathrm{ppm}$ for the adjacent N-4 (N-3) since for tetrazoles and triazoles these are the approximate shifts for protonation at one of the two identical $\mathrm{N}$-atoms, which are $\beta$ to the substituted pyrrole-type $\mathrm{N}$ atom. ${ }^{7}$ When the solution, which gave Figure $1 \mathrm{C}$ was carefully treated with $\mathrm{CD}_{3} \mathrm{OD}-\mathrm{D}_{2} \mathrm{O}(2.2: 1$, v/v $)$ at $-50^{\circ} \mathrm{C} \mathrm{HCl}$ gas was evolved generating a dilute $\mathrm{H}_{2} \mathrm{SO}_{4}$ solution and the ${ }^{15} \mathrm{~N}$ NMR spectrum changed to that of Figure 1D. For both of the protonated pentazoles $\mathbf{2}$ and $\mathbf{5}$ the neutral pentazole was freed from protonation as confirmed by (a) the restoration of its ${ }^{15} \mathrm{~N}$ NMR spectrum (with minor solvent effects), (b) its proton NMR spectrum (Fig. 1D inset), which was identical to that of an authentic sample in the same solvent mixture and (c) separate warming of the solution of regenerated pentazole to $-10^{\circ} \mathrm{C}$ whereupon the pentazole slowly decomposed to aryl azide and 
<smiles></smiles><smiles>C1#CCCC1</smiles><smiles></smiles>

(ii)

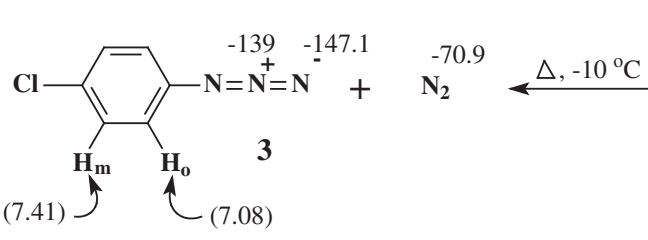<smiles>OCCNc1c(Cl)ccc(-n2nnnn2)c1NCCO</smiles><smiles></smiles>

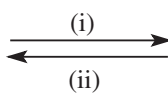<smiles></smiles>

Scheme 1. ${ }^{15} \mathrm{~N}$ NMR shifts from $\mathrm{MeNO}_{2}$ for ${ }^{15} \mathrm{~N}$-labelled $\left({ }^{*} \mathrm{~N}\right)$ substrates shown with ${ }^{1} \mathrm{H}$ shifts in parentheses: (i) $\mathrm{ClSO}_{3} \mathrm{H}$; (ii) $\mathrm{CD}_{3} \mathrm{OD}-\mathrm{D}_{2} \mathrm{O}(2.2: 1$, $\mathrm{v} / \mathrm{v})$; shifts for starting 1 and 4 in $\mathrm{CD}_{3} \mathrm{OD}-\mathrm{CD}_{2} \mathrm{Cl}_{2}(1: 1, \mathrm{v} / \mathrm{v})$, and for $\mathbf{1}$ regenerated from $\mathbf{2}$ in a mixture of $\mathrm{ClSO}_{3} \mathrm{H}\left(1.0 \mathrm{~cm}^{3}\right)$ and $\mathrm{CD}_{3} \mathrm{OD}-\mathrm{D}_{2} \mathrm{O}(2.2: 1$, $\left.\mathrm{v} / \mathrm{v}, 1.0 \mathrm{~cm}^{3}\right)$.
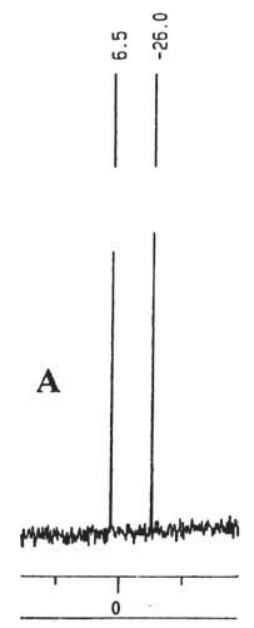
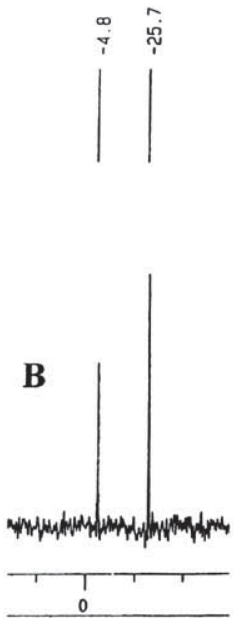
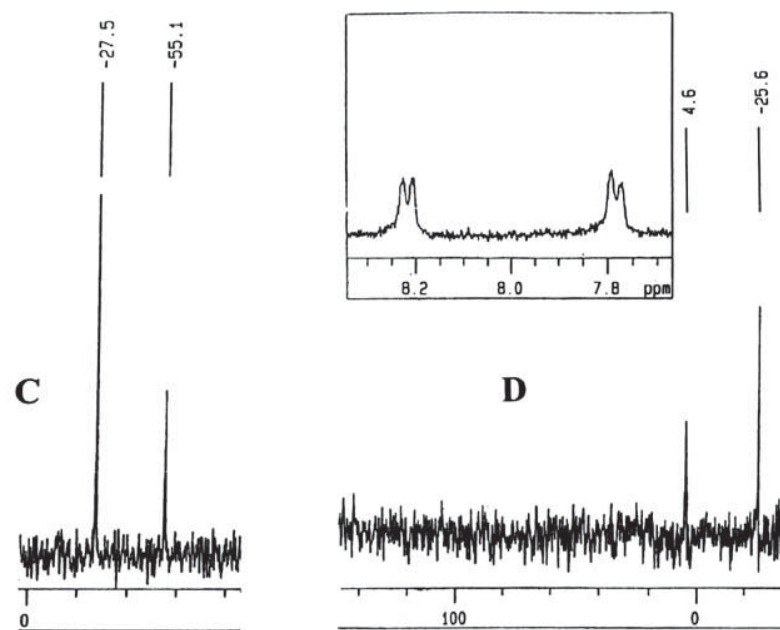

D

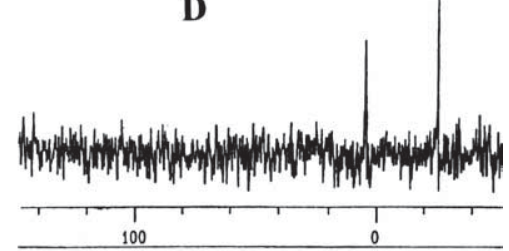

Figure 1. (A, C, D) ${ }^{15} \mathrm{~N}$ NMR spectra for $\mathbf{1}, 2$ and recovered 1, respectively, as in scheme; $(\mathrm{B})$ for $\mathbf{1}$ in $\mathrm{CF}_{3} \mathrm{CO}_{2} \mathrm{H}-\left(\mathrm{CF}_{3} \mathrm{CO}\right)_{2} \mathrm{O}(1: 1, \mathrm{v} / \mathrm{v})$.

$\mathrm{N}_{2}$ gas (Scheme 1). Hence in chlorosulfonic acid at $-40{ }^{\circ} \mathrm{C} 1$-aryl pentazoles are protonated at $\mathrm{N}-3$ and do not decompose.

The $-\mathrm{N}_{5}$ ring is the final member of the azole series, namely a very weak base, which protonates on the $\mathrm{N}$ atom, which is $\beta$ to the pyrrole-type $\mathrm{N}$ atom.

It is of interest that $\mathbf{4}$ protonates on the pentazole $\mathrm{N}-3$ and not on the ethereal oxygen. The $\mathrm{p} K_{\mathrm{a}}$ of protonated anisole is $-6.54 .^{11,12} \mathrm{~A} p-\mathrm{NO}_{2}$ group lowers the $\mathrm{p} K_{\mathrm{a}}$ of phenol by 2.74 units and since $\mathrm{HN}_{5}$ is a stronger acid than $\mathrm{HNO}_{3}{ }^{13}$ the $-\mathrm{N}_{5}$ substituent should lower the $\mathrm{p} K_{\mathrm{a}}$ of $\mathrm{MeO}^{+} \mathrm{H}-\mathrm{C}_{6} \mathrm{H}_{4} \mathrm{~N}_{5}$ to ca. -9 . This, combined with the increased basicity of the pentazole ring due to the electron donating $p$-methoxyphenyl substituent, is enough to direct protonation of compound 4 to $\mathrm{N}-3$.

\section{References and notes}

1. Huisgen, R.; Ugi, I. Angew. Chem. 1956, 68, 705-706; Huisgen, R.; Ugi, I. Chem. Ber. 1957, 90, 2914-2927.

2. A review: Butler, R. N. In Comprehensive Heterocyclic Chemistry II; Katritzky, A. R., Rees, C. W., Scriven, E. F. V., Eds.; Pergamon: Oxford, 1996; Vol. 4, pp 897-904.

3. Ugi, I. Angew. Chem. 1961, 73, 172. 
4. Benin, V.; Kaszynski, P.; Radziszewski, J. G. J. Org. Chem. 2002, 67, 1354-1358.

5. Mó, O.; de Paz, J. L. G.; Yáñez, M. J. Phys. Chem. 1986, 90, 5597-5604.

6. Jano, I. J. Phys. Chem. 1991, 95, 7694-7699.

7. Claramunt, R. M.; Sanz, D.; Boyer, G.; Catalán, J.; de Paz, J. L. G.; Elguero, J. Magn. Reson. Chem. 1993, 31, 791-800.

8. Catalán, J.; de Paz, J. L. G.; Yáñez, M.; Elguero, J. Chem. Scr. 1984, 24, 84-91.

9. A review: Schilf, W.; Stefaniak, L. In New Adv. Anal. Chem.; Atta-ur-Rahman, Ed.; Harwood Academic: Amsterdam, 2000; pp 659-696; Chem. Abstr. 2001, 134, 207413t.
10. A review of ${ }^{15} \mathrm{~N}$ NMR shifts for protonation of tetrazoles: Butler, R. N. In Comprehensive Heterocyclic Chemistry II; Katritzky, A. R., Rees, C. W., Scriven, E. F. V., Eds.; Pergamon: Oxford, 1996; Vol. 4, p 628 and p 664.

11. Smith, M. B.; March, J. Advanced Organic Chemistry, 5th ed.; Wiley Interscience: New York, 2001; p 329, and references cited therein; Gillespie, R. J.; Peel, T. E.; Robinson, E. A. J. Am. Chem. Soc. 1971, 93, 5083-5087.

12. McCollin Arnett, E.; Wu, C. Y. J. Am. Chem. Soc. 1960, $82,5660-5665$.

13. Chen, C. Int. J. Quant. Chem. 2000, 80, 27-37.

14. Butler, R. N.; Fox, A.; Collier, S.; Burke, L. A. J. Chem. Soc., Perkin Trans. 2 1998, 2243-2247. 